\title{
Pengaruh Model Pembelajaran Snowball Throwing Berbantuan Media Audiovisual terhadap Hasil Belajar Bahasa Indonesia
}

\author{
${ }^{*}$ Md Dwi Suria Oktaviani' ${ }^{1}$ I Wyn Suwatra ${ }^{2}$, Nym Murda ${ }^{3}$ \\ 1,2,3 Jurusan Pendidikan Guru Sekolah Dasar, FIP, Universitas Pendidikan Ganesha Singaraja, Indonesia
}

\author{
A R T I C L E I N F O \\ Article history: \\ Received 10 November \\ 2018 \\ Received in revised form \\ 09 December 2018 \\ Accepted 15 January 2019 \\ Available online 25 \\ February 2019
}

\section{Kata Kunci:}

hasil belajar, audiovisual,

snowball throwing.

Keywords:

achievement, audiovisual,

snowball throwing.

\begin{abstract}
A B S T R A K
Rendahnya hasil belajar bahasa Indonesia dengan model penelitian konvensional. Penelitian ini bertujuan untuk mengetahui perbedaan hasil belajar Bahasa Indonesia antara kelompok siswa yang dibelajarkan melalui model Snowball throwing berbantuan media audiovisual dan kelompok siswa yang tidak dibelajarkan melalui model pembelajaran Snowball throwing berbantuan media audiovisual pada siswa kelas V. Penelitian ini termasuk penelitian eksperimen semu dengan menggunakan non equivalent control group design. Populasi pada penelitian ini adalah seluruh siswa kelas $\mathrm{V}$ yang berjumlah 155 orang siswa. Pemilihan sampel menggunakan teknik random sampling, yang terdiri dari kelas eksperimen sebanyak 23 dan kelompok kontrol sebanyak 20 orang siswa. Data hasil belajar Bahasa Indonesia dikumpulkan dengan menggunakan metode tes dengan pilihan ganda, yang kemudian dianalisi menggunakan uji-t. Berdasarkan hasil analisis menunjukkan terdapat perbedaan hasil belajar Bahasa Indonesia antara kelompok siswa yang dibelajarkan melalui Snowball throwing berbantuan media audiovisual dan kelompok siswa yang tidak
\end{abstract} dibelajarkan melalui Snowball throwing berbantuan media audiovisual pada siswa kelas V. Dengan demikian dapat disimpulkan bahwa model Snowball throwing berbantuan media audiovisual berpengaruh terhadap hasil belajar Bahasa Indonesia siswa kelas V.

\begin{abstract}
A B S T RA C T
This study aims to determine the aimed of Indonesian subject achievement between groups of students who are taught through Snowball throwing model aided by audiovisual media and groups of students who are not taught through Snowball throwing model aided by audiovisual media on fifth grade students of fourth cluster Buleleng district. This research was quasi experimental research which used non equivalent control group design. The population of this research was all fifth grade students of fourth cluster district in academic year 2017/2018. The sample selection of this research used random sampling technique which obtained.. The data of Indonesian subject achievement were collected by using multiple choice tests which were analyzed by using t-test. Based on the data analysis obtained tCount $=7,058$ and ttable $=2,021$ at significant level of $5 \%$ with dk $=41(n 1+n 2-2$ $=23+20-2=41$ ). This means that there are differences in Indonesian subject achievement between groups of students who are taught through Snowball throwing aided by audiovisual media and groups of students who are not taught through Snowball throwing aided by audiovisual media on fifth grade students of fourth cluster district in academic year 2017/2018. Thus it can be concluded that Snowball throwing model aided audiovisual media influenced on Indonesian subject achievement of fifth grade students of fourth cluster Buleleng district in academic year 2017/2018.
\end{abstract}

Copyright (c) Universitas Pendidikan Ganesha. All rights reserved. 


\section{Pendahuluan}

Tujuan pendidikan nasional adalah mencerdasakan kehidupan bangsa dan mengembangkan manusia Indonesia seutuhnya. Manusia seutuhnya adalah manusia yang berimam dan bertaqwa terhadap Tuhan Yang Maha Esa dan berbudi pekerti luhur, memiliki pengetahuan, keterampilan, kesejahtraan jasmani dan rohani, keperibadian yang mantap dan mandiri serta tanggung jawab kemasyarakatan dan kebangsaan. Tujuan pendidikan dapat dicapai dengan meningkatkan mutu pendidikan. Peningkatan mutu pendidikan dapat dilakukan dengan memperbarui proses pembelajaran, memperbaiki kurikulum yang ada dan mengatasi permasalahan yang ada dalam pendidikan(Suyono, 2011). Sehingga diharapkan melalui pendidikan nasional, sumber daya manusia Indonesia menjadi sumber daya manusia yang berkualitas dan mampu bersaing dengan negara- negara lain. Bahasa Indonesia merupakan mata pelajaran yang menanamkan dan mengembangkan penguasaan pengetahuan, keterampilan berbahasa, dan sikap positif terhadap bahasa dan sastra Indonesia. Oleh sebab itu guru hendaknya menyadari bahwa tujuan pembelajaran bahasa Indonesia bukan hanya menyediakan teori - teori saja, tetapi juga untuk mengembangkan keterampilan berbahasa dan sikap positif terhadap bahasa dan sastra Indonesia. Untuk mencapai tujuan tersebut guru diharapkan lebih kreatif dalam mengembangkan aktivitas pembelajaran agar siswa lebih aktif, kreatif dan inovatif dalam mengikuti pembelajaran. Dalam hal ini guru harus mampu membuat suasana yang kondusif pada saat proses pembelajaran. Suasana belajar yang kondusif dapat terwujud jika pembelajaran diikuti aktif oleh seluruh siswa.

Namun tidak demikian kenyatannya. Berdasarkan obeservasi yang dilakukan pada tanggal 23 November hingga tanggal 30 November 2017 terhadap enam guru kelas V yang berada di Gugus IV Kecamatan Buleleng. Hasil yang diperoleh dari wawancara adalah tiga dari enam guru mengatakan kurang mengetahui bagaimana menciptakan suasana pembelajaran yang dapat membuat siswa menjadi aktif dalam pembelajaran, empat guru mengatakan sulit untuk memadukan model pembelajaran agar pembelajaran selesai sesuai dengan tanggal yang telah ditentukan di program pelaksanaan pembelajaran, enam guru kelas V di Gugus IV Kecamatan Buleleng lebih banyak menggunakan metode ceramah, tanya jawab dan penugasan yang diberikan secara terus menerus agar pembelajaran selesai sesuai dengan tanggal yang ditentukan dan agar tidak ada materi yang tertinggal sebelum ulangan akhir semester, mengingat materi yang diberikan kepada siswa haruslah lengkap dengan waktu yang terbatas, sehingga siswa tidak sepenuhnya memahami materi yang diberikan dan pembelajaran menjadi tidak terlaksana secara maksimal.

Hasil yang diperoleh dari observasi di dalam kelas pada saat pembelajaran adalah dalam mengikuti pembelajaran, hanya beberapa siswa memperoleh pringkat didalam kelas yang lebih banyak aktif untuk menjawab pertanyaan yang diberikan oleh guru, siswa enggan untuk bertanya apabila mengalami kesulitan atau belum mengerti dengan penjelasan guru karena malu untuk berbicara didalam kelas, proses pembelajaran yang dilakukan guru lebih banyak menggunakan metode ceramah, tanya jawab dan penugasan, dalam pembelajaran guru tidak menggunakan media sehingga pembelajaran menjadi monoton, sehingga membuat siswa mudah jenuh dalam mengikuti pembelajaran, siswa tidak dapat menjelaskan kembali mengenai materi pembelajaran yang telah dipelajari, hal ini disebabkan karena kurangnya keaktifan siswa dikelas dan kurangnya pengetahuan siswa dalam menemukan ide pokok dari persoalan yang diberikan, sehingga siswa mengalami kesulitan dalam penyampaian materi yang sudah diajarkan. Selain wawancara dan observasi di dalam kelas, dilakukan pencatatan dokumen. Pencatatan dokumen diperoleh dari nilai rata - rata Ulangan Tengah Semester mata pelajaran Bahasa Indonesia dari guru kelas V di Gugus IV Kecamatan Buleleng tahun pelajaran 2017/ 2018. Adapun rata- rata nilai Ulangan Tengah Semester mata pelajaran Bahasa Indonesia siswa kelas V di Gugus IV Kecamatan Buleleng tahun pelajaran 2017/ 2018.

Berdasarkan Tabel 1 terlihat bahwa masih banyak nilai siswa yang belum mencapai KKM yang diterapkan oleh sekolah, sehingga hasil belajar Bahasa Indonesia siswa belum maksimal dan perlu ditingkatkan. Oleh karena hasil belajar Bahasa Indonesia siswa yang belum mencapai KKM yang ditentukan oleh sekolah, perlu dicarikan solusi. Salah satu solusi yang dapat digunakan adalah menciptakan pembelajaran yang inovatif dan menciptakan suasana belajar yang aktif. Pembelajaran inovatif dapat meningkatkan minat siswa untuk belajar Bahasa Indonesia dan dapat mendorong siswa untuk lebih berperan aktif dalam pembelajaran, sehingga siswa akan dituntun untuk menemukan jawaban sendiri dari suatu permasalahan yang diberikan. Untuk meningkatkan hasil belajar siswa. diberikan satu solusi yang tepat adalah melakukan inovasi pembelajaran(Apriani, Suwatra, \& Margunayasa, 2017). Model pembelajaran merupakan faktor pendukung yang mempunyai peranan cukup besar dalam pembelajaran. Pemilihan model pembelajaran yang tepat dan sesuai dengan materi akan membuat siswa lebih tertarik dalam mengikuti pembelajaran dan dapat meningkatkan keaktifan siswa dalam pembelajaran. 
Pembelajaran yang diperlukan saat ini adalah pembelajaran yang kreatif dan inovatif, yaitu salah satunya mengembangkan pembelajaran yang berorientasi pada model pembelajaran kooperatif. Model pembelajaran kooperatif adalah kegiatan pembelajaran dengan cara berkelompok yang terdiri dari siswa yang heterogen untuk bekerja sama saling membantu memahami materi pelajaran dan menyelesaikan tugas. Model pembelajaran kooperatif terdiri dari bermacam-macam jenis, diantaranya yaitu model pembelajaran Jigsaw, model pembelajaran STAD (Student Teams Achievement Division), model pembelajaran NHT (Numbered Head Together), model pembelajaran Snowball Throwing, dan sebagainya. Tiap-tiap jenis model pembelajaran memiliki langkah-langkah tersendiri untuk digunakan di dalam kegiatan pembelajaran, sehingga satu model pembelajaran yang cocok digunakan untuk suatu kompetensi, belum tentu pula cocok digunakan untuk kompetensi yang lainnya karena tiap kompetensi memiliki ciri sendirisendiri (Irwan \& Suharmanto, 2014). Salah satu model pembelajaran inovatif yang dapat diterapkan dalam pembelajaran bahasa Indonesia disekolah dasar adalah model pembelajaran kooperatif tipe Snowball throwing (bola salju bergulir)(Putri \& Agustyaningrum, 2017). Menurut Winahyu (2016) model pembelajaran Snowball Throwing adalah model pembelajran inovatif, yang lebih berfokus kepada siswa sebagai pusat pembelajaran. Model pembelajran ini cukup menyenangkan untuk digunakan dalam mengulangi mateti pembelajaran yang telah diberikan sebelumnya karena siswa dapat belajar sambuil bermain. Pembelajaran kooperatif model Snowball Throwing bertujuan agar siswa cenderung aktif memberikan saran pada saat proses pembelajaran. Pada model pembelajaran ini menuntut peran aktif, meningkatkan interaksi dan bertukar pikiran sehingga mampu meningkatkan hasil belajar yang merupakan tujuan utama dari adanya suatu pembelajaran. Menurut Adhiatmika, Agustini, \& I Gede Partha Sindu (2017) model pembelajaran Snowball Throwing adalah jenis pembelajaaran kooperatif yang didesain seperti permainan melempar bola. untuk mengarahkan potensi peserta didik terhadap materi kelompok melalui suatu permainan yang memanfaatkan selembar kertas yang dibentuk seperti bola lalu dilemparkan ke siswa dengan cara membagi siswa kedalam beberapa kelompok. Menurut (Astuti, 2017) pembelajaran dengan menggunakan Snowball Throwing dapat menciptakan rasa kebersamaan dalam kelompok baik antar anggota kelompok maupun dengan anggota kelompok lain. Model pembelajaran Snowball throwing merupakan pengembangan dari model pembelajaran diskusi dan merupakan bagian model pembelajaran kooperatif (Shoimin, 2014:174). Model ini memadukan pendekatan komunikatif, integrative, dan keterampilan proses. Jika proses pembelajaran berjalan dengan lancar maka akan terbentuk suasana kelas yang nyaman untuk anak belajar, karena dalam proses pembelajaran siswa tidak hanya melakukan aktivitas berbicara, bertanya, menulis dan juga berfikir pada saat pembelajaran tetapi siswa juga melakukan aktivitas fisik dengan menggulung kertas dan melemparkan kepada siswa lain. Dengan demikian setiap siswa akan mempersiapkan diri untuk menjawab pertanyaan dari siswa lain yang terdapat pada bola kertas.

Disamping penggunaan model pembelajaran, pembelajaran akan berjalan lebih menyenangkan jika diikuti dengan penggunaan media, misalnya penggunaan media audiovisual. Media audiovisual merupakan salah satu media elektronik perpaduan antara audio (suara) dan visual (gambar). Diantara jenis audiovisual adalah media film, televisi dan video. Pembelajaran yang dilakukan dengan menggunakan media tentu akan membuat siswa akan membuat fokus pada pembelajaran. Pada penelitian ini penggunaan media yang digunakan adalah video pembelajaran.

Berdasarkan temuan dan permasalahan yang dihadapi, perlu dilakukan penelitian tentang "Pengaruh Model Pembelajaran Kooperatif Tipe Snowball throwing Berbantuan Media Audio visual Terhadap Hasil Belajar Bahasa Indonesia Siswa Kelas V Gugus IV Kecamatan Buleleng Tahun Pelajaran 2017/ 2018".

Berdasarkan uraian diatas maka dilakukan penelitian dengan judul "Pengaruh model pembelajaran Snowball throwing berbantuan media audiovisual terhadap hasil belajar bahasa indonesia siswa kelas V Gugus IV Kecamatan Buleleng tahun pelajaran 2017/ 2018”. Hasil temuan penelitian pada penelitian ini memiliki persamaan dengan penelitian yang relevan sebelumnya dan memperkuat hasil penelitian yang diperoleh. Didukung oleh hasil penelitian Handayani, Mujasam, Sri Wahyu Widyaningsih, \& Irfan Yusuf, (2017) bahwa proses pembelajaran dengan menggunakan model kooperatif tipe Snowball throwing dapat meningkatkan hasil belajar peserta didik. Ambarsari (2014) dalam penelitiannya menyimpulkan bahwa penggunaan model pembelajaran kooperatif tipe Snowball Throwing pada materi kingdom plantae dapat meningkatkan aktivitas belajar siswa dan berpengaruh dalam meningkatkan penguasaan materi siswa. Rosidah (2017) model pembelajaran tipe Snowball Throwing dapat meningkatkan hasil belajar siswa yaitu dilihat dari siklus I jumlah siswa dari 21 orang ada 15 orang yang tuntas sebanyak $71,42 \%$ meningkat di siklus II menjadi 18 orang dari 21 siswa yang dikatakan tuntas yaitu 85,71\%. Oleh karena itu hasil balajar siswa melalui model pembelajaran tipe Snowball Throwing dapat meningkatkan hasil belajar siswa terbukti dari hasil peningkatan siklus I ke siklus II. 
Penelitian ini bertujuan untuk mengetahui perbedaan hasil belajar bahasa indonesia antara kelompok siswa yang dibelajarkan melalui model pembelajaran Snowball throwing berbantuan media audiovisual dan kelompok siswa yang tidak dibelajarkan melalui model pembelajaran Snowball throwing berbantuan media audiovisual pada siswa kelas V Gugus IV Kecamatan Buleleng Tahun Pelajaran 2017/ 2018.

\section{Metode}

Jenis penelitian ini adalah eksperimen semu. Penelitian ini menggunakan desain non equivalent control group design. Populasi dalam penelitian ini adalah seluruh siswa kelas V Gugus IV Kecamatan Buleleng yang berjumlah 155 orang. Sampel yang diuji telah diuji kesetaraanya menggunakan analisis varians satu jalur (Anava A) dengan hasil fhitung=0.33 lebih kecil dibandingkan ftabel = 2,27. Sampel pada penelitian ini adalah siswa kelas V di SD Negeri 3 Penglatan sebagai kelompok eksperimen yang berjumlah 23 orang dan SD Negeri 3 Alasangker sebagai kelompok kontrol yang berjumlah 20 orang yang di pilih dengan melakukan teknik random sampling. Pada penelitian ini terdapat dua variabel yaitu variabel terikat dan variabel kontrol. Variabel terikat pada penelitian ini adalah hasil belajar bahasa Indonesia dan variabel bebas pada penelitian ini adalah model pembelajaran Snowball throwing berbantuan media audiovisual.

Metode pengumpulan data pada penelitian ini dengan menggunakan tes objektif atau tes pilihan ganda. Setelah dilakukannya model Snowball throwing berbantuan media audiovisual dan model konvensional. Sebelum memberikan instrumen, dilakukan uji coba terlebih dahulu untuk mengetahui kelayakannya dengan melakukan uji validitas, uji reliabilitas, uji daya beda, dan uji tingkat kesukaran(Sugiyono, 2015). Uji validitas isi dilakukan dengan berkonsultasi dengan pakar (judges) terkait dengan soal untuk mengukur hasil belajar dengan hasil perhitungan 1,00 dengan kategori sangat tinggi, kemudia tes hasil belajar diuji cobakan ke sekolah dengan menggunakan kelas VI di Gugus IV kecamatan buleleng sebagai responden yang berjumlah 48 siswa, diperoleh 31 butir tes valid dari 41 butir soal yang di uji cobakan. Kemudian untuk uji reliabilitas diperoleh koefisien reliabilitas sebesar 0,884 dengan kategori sangat tinggi. Kemudian hasil perhitungan uji daya beda diperoleh 0,52 dengan kategori cukup baik, dan bedasarkan uji coba tingkat kesukaran tes hasil belajar diperoleh (Pp) 0,76 dengan kategori mudah. Metode yang digunakan pada penelitian ini yaitu analisis statistik deskriptif dan analisis statistik infrensial. Metode yang dugunakan untuk menguji hipotesis pada penelitian ini adalah uji-t. Sebelum melakukan hipotesis dengan menggunakan statistik inferensial , terlebih dahulu dilakukan uji prasyarat analisis meliputi uji normalitas dan uji homogenitas. Pada uji normalitas menggunakan uji Chi- Kuadrat dan pada uji homogenitas varians dengan menggunakan uji F.

\section{Hasil dan Pembahasan}

Data yang dikumpulkan pada penelitian ini adalah data hasil belajar bahasa Indonesia siswa dari kelompok eksperimen dan kelompok kontrol diperoleh melalui posttest. Pada kelompok eksperimen data hasil belajar terhadap 23 siswa dengan skor tertinggi 26 dan skor terendah adalah 16. Dari skor yang diperoleh dapat dideskripsikan yaitu mean $(M)=21,57$, Median $(M d)=22,5$ Modus $(M o)=24,06$ standar deviasi $(s)=3,12$, dan varians $\left(s^{2}\right)=9,71$. Data hasil belajar bahasa indonesia pada kelompok eksperimen dapat disajikan dalam bentuk kurva polygon seperti pada Gambar 1. 


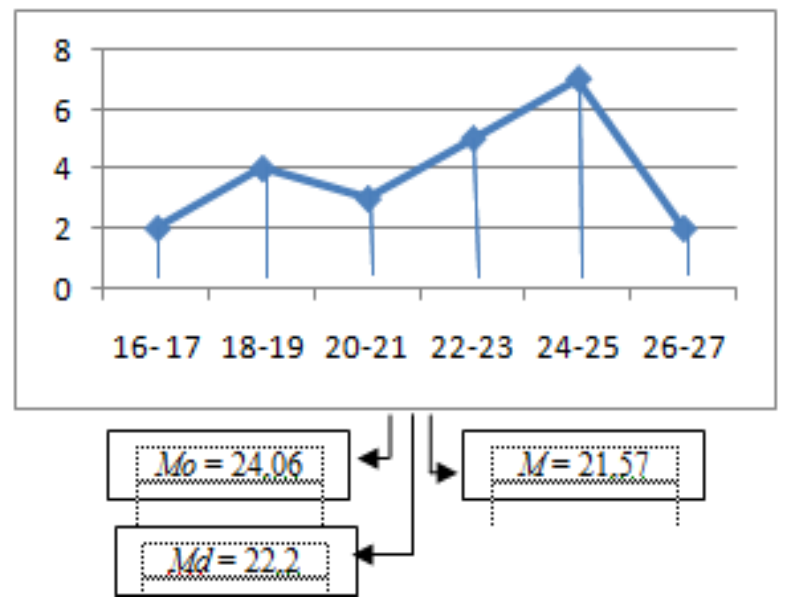

Gambar 1

Kurva Polygon data hasil belajar pada kelas eksperimen.

Berdasarkan kurva polygon diatas diketahui $M o>M d>M$. Sehingga kurva yang terbentuk adalah kurva juling negatif. Artinya sebagian besar skor yang diperoleh cendrung tinggi.

Data hasil belajar bahasa Indonesia kelompok kontrol diperoleh melalui posttest terhadap 20 orang siswa dengan skor tertinggi 20 dan skor terendah adalah 11. Dari skor yang diperoleh dapat dideskripsikan yaitu Mean $(M)=15,5$ Median $(M d)=15$ Modus $(M o)=13,76$ standar deviasi $(\mathrm{s})=2,62$ varians $\left(s^{2}\right)=6,89$. Data hasil belajar bahasa indonesia pada kelompok eksperimen dapat disajikan dalam bentuk kurva polygon seperti pada Gambar 2.

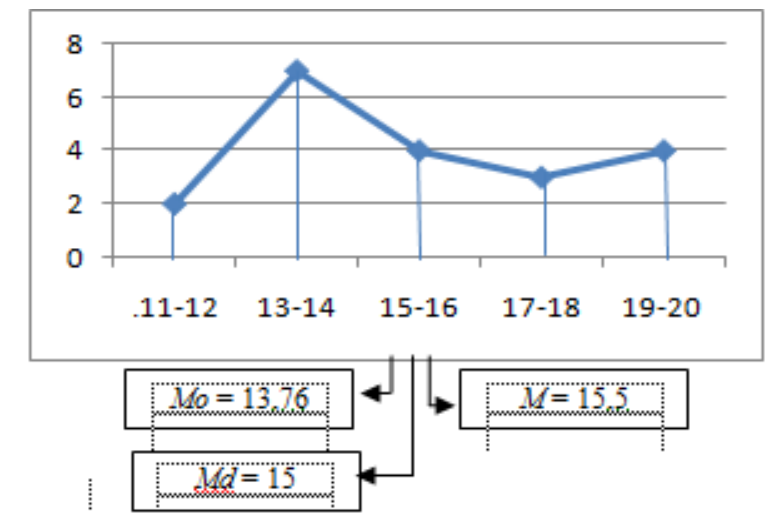

Gambar 2

Kurva Ploygon data hasil belajar pada kelas kontrol

Berdasarkan kurva polygon diatas diketahui $M o<M d<M$. Sehingga kurva yang terbentuk adalah kurva juling positif. Artinya sebagian skor cendrung rendah. Berdasarkan uraian hasil deskripsi data hasil belajar bahasa Indonesia pada kelompok eksperimen dan kelompok kontrol dapat ditentuan tinggi rendahnya kualitas kedua variabel. Untuk menentukan skor rata- rata atau mean tiap- tiap variabel dikonversikan dengan menggunakan kreteria rata- rata ideal $\left(\mathrm{M}_{\mathrm{i}}\right)$ dan standar deviasi $\left(\mathrm{SD}_{\mathrm{i}}\right)$. sebelum dimasukan ke dalam konversi skala lima, hitung terlebih dahulu rata-rata skor(mean) dan standar deviasi(SD). Berdasarkan perhitungan data hasil belajar pada kelompok eksperimen dan kelompok kontrol dapat ditentukan tinggi rendahnya hasil belajar dengan kualifikasi menggunakan pedoman konversi skala lima dapat disajikan pada tabel

Tabel 2 Skala Konversi Kategori Hasil Belajar Bahasa Indonesia Kelompok Eksperimen dan kelompok Kontrol

\begin{tabular}{ll}
\hline Rentangan Skor & Klasifikasi/Predikat \\
\hline
\end{tabular}




\begin{tabular}{lc}
\hline $22,5 \leq M \leq 30$ & Sangat tinggi \\
$17,5 \leq M<22,5$ & Tinggi \\
$12,5 \leq M<17,5$ & Sedang \\
$7,5 \leq M<12,5$ & Rendah \\
$0 \leq M<7,5$ & Sangat Rendah \\
\hline
\end{tabular}

Nilai rata- rata pada kelompok eksperimen yang dibelajarkan melalui model pembelajaran Snowball throwing berbantuan media audiovisual adalah 21,57. Berdasarkan tabel terletak pada kategori tinggi. Sedangkan nilai rata- rata pada kelompok kontrol yang tidak dibelajarkan melalui model pembelajaran Snowball throwing berbantuan media audiovisual adalah 15,5 Berdasarkan tabel terletak pada kategori sedang. Setelah melakukan analisis data, dapat disajikan hasil uji normalitas sebaran data bahasa Indonesia kelompok eksperimen dan kontrol pada Tabel 3.

Tabel 3. Ringkasan hasil uji normalitas

\begin{tabular}{lllll}
\hline Kelompok & $\mathrm{X}^{2}$ hitung & & $\mathrm{X}^{2}$ tabel & Keterangan \\
\hline Eksperimen & 4,09 & $<$ & 7,185 & Normal \\
Kontrol & 4,61 & $<$ & 5,591 & Normal \\
\hline
\end{tabular}

Berdasarkan hasil perhitungan menggunakan rumus Chi- kuadrat, diperoleh hasil pada kelompok eksperimen $\mathrm{X}^{2}$ hitung $=4,09$ dan $\mathrm{X}^{2}$ tabel pada taraf signifikan $5 \%$ dan $\mathrm{dk}=3$ adalah 7,185. Hal ini berarti $\mathrm{X}^{2}$ hitung hasil belajar pada kelompok eksperimen lebih kecil dari $\mathrm{X}^{2}$ tabel, sehingga skor data hasil belajar bahasa Indonesia berdistribusi normal. Hasil perhitungan pada kelompok kontrol $\mathrm{X}^{2}$ hitung $=4,61$ dan $\mathrm{X}^{2}$ tabel pada taraf signifikan 5\% dan dk 2 adalah 5,591. Hal ini berarti $X^{2}$ hitung hasil belajar pada kelompok kontrol lebih kecil dari $\mathrm{X}^{2}$ tabel, sehingga skor data hasil belajarbahasa Indonesia berdistribusi normal.

Pada penelitian ini uji homogenitas varians dilakukan terhadap varians antar kelompok eksperimen dan kelompok kontrol. Uji yang digunkaan adalah uji $\mathrm{F}$ dengan kreteria homogen jika Fhitug $<\mathrm{F}_{\text {tabel.. }}$ Perhitungan uji homogenitas sebaran data secara lengkap disajikan pada tabel 4.

Tabel 4 Rangkuman Hasil Uji Homogenitas Varians antar Kelompok Eksperimen dan Kontrol

\begin{tabular}{lllll}
\hline Sumber data & $\mathrm{F}_{\text {hitung }}$ & $\mathrm{F}_{\text {tabel }}$ & Status \\
\hline $\begin{array}{l}\text { Post-test Kelompok } \\
\text { dan Kontrol }\end{array}$ & Eksperimen & 1,40 & 4,08 & Homogen \\
\hline
\end{tabular}

Berdasarkan tabel 4 diketahui $\mathrm{F}_{\text {hitung }}$ hasil belajar dari kelompok eksperimen kontrol adalah 1,40. Sedangkan $\mathrm{F}_{\text {tabel }}$ pada df1 = 1, df2= 41, dan taraf signifian $5 \%$ adalah 4,08. Hal ini berarti varians data hasil belajar bahasa Indonesia adalah homogen.

Untuk pembuktian hipotesis yang diajukan dengan menggunakan uji-t dengan menggunakan rumus polled varians. Adapun analisis uji-t disajikan pada Tabel 5.

Tabel 5. Rangkuman Hasil Uji-t

\begin{tabular}{llllll}
\hline Kelompok & $\mathrm{N}$ & Mean & $\mathrm{s}^{2}$ & $\mathrm{t}_{\text {hitung }}$ & $\mathrm{t}_{\text {tabel }}$ \\
\hline Eksperimen & 23 & 21,57 & 9,71 & & \\
Kontrol & 20 & 15,5 & 6,89 & 7,058 & 2,021 \\
\hline
\end{tabular}

Dari ringkasan diatas dinyatakan bahwa thitung 7,058 lebih besar dari pada tabel 2,021 pada taraf signifikan 5\% dengan kreteria hitung ( $t_{\text {hitung }}>t_{\text {tabel }}$ ). Maka analisis dengan uji $t$ dari hasil kelompok eksperimen dan kelompok kontrol adalah $t_{\text {hitung }}(7,058)>t_{\text {tabel }}(2,021)$ pada taraf signifikansi $5 \%$, maka data tersebut dinyatakan signifikan. Artinya, terdapat perbedaan hasil belajar bahasa indonesia antara kelompok siswa yang dibelajarkan melalui model pembelajaran Snowball throwing berbantuan media audiovisual dan kelompok siswa yang tidak dibelajarkan melaui model pembelajaran Snowball throwing media audiovisual pada siswa kelas V Gugus IV Kecamatan Buleleng Tahun Pelajaran 2017/ 2018. 
Berdasarkan skor rata- rata yang diperoleh menunjukan bahwa rata - rata hasil belajar Bahasa Indonesia yang dibelajarkan melalui model pembelajaran Snowball throwing berbantuan media audiovisual memperoleh skor 21,57 yang lebih tinggi dari rata- rata skor hasil belajar pada kelompok siswa yang tidak dibelajarkan melalui model pembelajaran Snowball throwing berbantuan media audiovisual, yang memiliki rata- rata skor 15,5. Hal ini menunjukan bahwa model pembelajaran Snowball throwing berbantuan media audiovisual yang diterapkan dalam pembelajaran Bahasa Indonesia lebih baik diterpkan dalam pembelajaran untuk meningkatkan hasil belajar dibandingkan dengan model pembelajaran yang konvensional

Pada proses pembelajaran dengan menggunakan model snowball throwing, dapat memberikan kesempatan bagi siswa untuk dapat mengaktifkan diri dalam proses pembelajaran dan siswa lebih tertarik dalam mengikuti pembelajaran karena dalam pembelajaran siswa terlibat langsung. Penggunaan model Snowball throwing dapat meningkatkan semangat siswa dalam belajar karena pembelajaran yang dilakukan dengan menggunakan model pembelajaran berbeda dengan pembelajaran yang cendrung guru lebih banyak menggunakan metode berceramah. Dalam proses pembelajaran dengan menggunakan model pembelajaran Snowball throwing siswa diajak untuk aktif dalam pembelajaran dengan membuat pertanyaan yang dibuat di kertas lempiran kemudian diremas menyerupai bola oleh siswa. Sehingga siswa dapat terjun aktif dalam mengikuti proses pembelajaran. Penerapan model pembelajaran Snowball throwing juga didukung dengan penggunaan media audiovisual. Media audiovisual yang digunakan dalam penelitian ini adalah video pembelajaran. Melalui penggunaan media audiovisual dapat mempermudah siswa dalam mengiktui proses pembelajaran. Sehingga dapat menumbuhkan motivasi dalam belajar dan menumbuhkan keaktifan siswa di dalam mengikuti proses pembelajaran. Pembelaran yang diduung dengan menggunakan media akan menumbuhkan semangat belajar siswa dan dapat meningatkan konsentrasi siswa dalam belajar.

Hasil penelitian ini sejalan dengan penelitian yang dilakukan oleh Sandi (2014) dengan judul "Pengaruh Model Pembelajaran Snowball throwing Terhadap Hasil belajar IPA Dengan Kovariabel Kemampuan Berfikir Kreatif Siswa Kelas IV SD". Dalam hasil penelitiannya menunjukan terdapat perbedaan hasil belajar Bahasa Indonesia siswa kelas IV Gugus X Kelurahan kaliuntu antara siswa yang mengikuti model pembelajaran dengan model pembelajaran Snowball throwing dengan model pembelajaran konvensional. Pada penelitian ini kelompok siswa yang dibelajarkan dengan menggunakan model pembelajaran Snowball throwing rata- rata nilai siswa lebih tinggi dibandingkan dengan kelompok siswa yang dibelajarkan dengan model pembelajaran konvensional. Hasil penelitian lain yang mendukung penelitian ini adalah penelitian yang dilakukan oleh (Susanti, 2014)Susanti, dkk ( 2014) dengan judul" Pengaruh Model Snowball throwing berbantuan Media Konkrit terhadap hasil belajar IPA Kelas V SD Gugus 1 Gusti Ngurah Rai Denpasar". hasil penelitiannya menunjukan terdapat perbedaan hasil belajar IPA anatara kelompok siswa yang dibelajarkan melalui model pembelajaran Snowball throwing berbantuan media konkrit dengan kelompok siswa yang dibelajarkan melalui model pembelajaran konvensional.

Peneliti lain yang mendukung temuan ini adalah Gunawan \& Dkk (2016) dengan judul "Pengaruh Pendekatan Saintifik Dengan Teknik Snowball throwing Terhadap Kompetensi Pengetahuan IPS Siswa Kelas IV". Hasil penelitian tersebut menunjukan terdapat perbedaan yang signifikan kompetensi pengetahuan siswa yang dibelajarkan melalui pendekatan saintifik dengan teknik snowball throwing. Berbeda dengan kelompok kontrol yang tidak menggunakan model pembelajaran Snowball throwing berbantuan media audiovisual. Pembelajaran yang dilakukan cendrung guru yang lebih aktif untuk memberian materi dalam proses pembelajaran. Pembelajaran yang dilakuan di kelas kontrol berpusat pada guru yang mencakup pemberian informasi oleh gurunya, tanya jawab, pemberian tugas oleh guru, pelaksanaan tugas oleh siswa sampai pada akhirnya guru merasa bahwa apa yang telah diajarkan dapat dimengerti oleh siswa. Pembelajaran yang jarang melibatkan pengaktifan pengetahuan awal dan jarang memotivasi siswa untuk proses pengetahuannya, sehingga siswa merasa bosan dalam mengikuti pembelajaran dan kurang konsentrasi dalam mengikuti pembelajaran. Pembelajaran masih didasarkan atas asumsi bahwa pengetahuan dapat dipindahkan secara utuh dari pikiran guru ke pikiran siswa sehingga siswa tidak bisa mengembangkan proses belajarnya secara optimal.

Hasil penelitian ini membuktikan bahwa terdapat Perbedaan hasil belajar Bahasa Indonesia antara kelompok siswa yang dibelajarkan menggunakan model pembelajaran Snowball throwing berbantuan media audiovisual dengan kelompok siswa yang tidak dibelajaran menggunakan model pembelajaran Snowball throwing berbantuan media audio visual pada siswa kelas V Gugus IV Kecamatan Buleleng tahun pelajaran 2017/2018. Hasil belajar Bahasa Indonesia siswa yang mengikuti model pembelajaran Snowball throwing berbantuan media audiovisual lebih tinggi dari pada hasil belajar Bahasa Indonesia kelompok siswa yang tidak dmengikuti model pembelajaran Snowball throwing berbantuan media audiovisual. Dengan demikian, Snowball throwing berpengaruh terhadap hasil belajar Bahasa Indonesia siswa. 


\section{Simpulan dan Saran}

Berdasarkan rumusan masalah dan hasil penelitian di atas maka, dapat disimpulkan bahwa terdapat perbedaan hasil belajar Bahasa Indonesia antara kelompok siswa yang dibelajarkan melalui model pembelajaran Snowball throwing berbantuan media audio visual dengan kelompok siswa yang tidak dibelajaran melalui model pembelajaran Snowball throwing berbantuan media audio visual pada siswa kelas V Gugus IV Kecamatan Buleleng tahun pelajaran 2017/2018. Berdasarkan hasil uji hipotesis dengan uji-t diperoleh nilai thitung sebesar 7,058 dan ttabel sebesar 2,021 (dengan taraf signifikansi 5\% dan dengan $\mathrm{db}=41$ ). Hasil analisis menunjukkan bahwa thitung lebih besar daripada ttabel yaitu 7,058 > 2,021 sehingga H0 ditolak dan H1 diterima. Artinya model pembelajaran kooperatif tipe Snowball throwing berbantuan media audiovisul memiliki pengaruh terhadap hasil belajar Bahasa Indonesia siswa kelas V SD Gugus IV Kecamatan Buleleng Tahun Pelajaran 2017/2018.

Adapun saran yang dapat disampaikan setelah melaksanakan dan memperoleh hasil penelitian ini yaitu : 1) bagi siswa agar lebih aktif dalam mengikuti pembelajaran untuk meningkatkan hasil belaajar, 2) bagi guru agar lebih kreatif dalam mengemas pembelajaran dengan menggunakan model pembelajaran yang sesuai dengan karakteristik siswa dan materi ajar yang bertujuan untuk meningkatkan semangat siswa dalam belajar dan juga dapat meningkatkan hasil belajar, 3) bagi kepala sekolah agar selalu berupaya meningkatkan kualitas pembelajaran agar siswa nyaman dalam belajar dan bersemangat untuk belajar, 4) peneliti lain agar mampu mengembangkan penelitian ini dengan melihat kendala- kendala dalam penelitian ini dan dapat dijadikan sebagai referensi

\section{Daftar Rujukan}

Adhiatmika, M. W., Agustini, K., \& I Gede Partha Sindu. (2017). Pengaruh Model Pembelajaran Kooperatif Tipe Snowball Throwing Terhadap Hasil Belajar Siswa Pada Mata Pelajaran TIK Kelas VIII SMP Negeri 5 Tejakula. Kumpulan Artikel Mahasiswa Pendidikan Teknik Informatika (KARMAPATI), 6(1), $1-10$.

Ambarsari, D. (2014). Pengaruh Penggunaan Model Pembelajaran Snowball Throwing terhadap Aktivitas Belajar dan Penguasaan Materi. Jurnal Bioterdidik, 2(1).

Apriani, N. K. P., Suwatra, I. I. W., \& Margunayasa, I. G. (2017). NPengaruh Model Pembelajaran Snowball throwing terhadap Hasil Belajar IPS Siswa Kelas V SD. E-Journal PGSD Pendidikan Ganesha Mimbar $P G S D, 5(2)$.

Astuti, S. (2017). Supervisi Akademik Untuk Meningkatkan Kompetensi Guru Di SD Laboratorium UKSW. Scholaria, 7(1), 49-59.

Gunawan, J., \& Dkk. (2016). Pengaruh Pendekatan Saintifik Dengan Teknik Snowball throwing Terhadap Kompetensi Pengetahuan IPS Siswa Kelas IV. E-Journal PGSD Pendidikan Ganesha Mimbar PGSD, 6(3).

Handayani, T., Mujasam, Sri Wahyu Widyaningsih, \& Irfan Yusuf. (2017). Penerapan Model Pembelajaran Kooperatif Tipe Snowball Throwing terhadap Hasil Belajar Peserta Didik. Jurnal Curricula, 2(1), 47 58.

Irwan, Z., \& Suharmanto, A. (2014). Perbedaan Hasil Belajar Kompetensi Menjelaskan Prosesproses Mesin Konversi Energi Menggunakan Model Pembelajaran Snowball Throwing dengan Model Pembelajaran Langsung. Journal of Mechanical Engineering Learning (JMEL), 3(1), 47-55.

Putri, I. S., \& Agustyaningrum, N. (2017). Efektivitas Model Pembelajaran Problem Based Instruction Dan Snowball Throwing Ditinjau Dari Hasil Belajar Matematika Siswa Kelas VIII SMP N 51 Batam. Jurnal Mercumatika, 1(2), 97-103.

Rosidah, A. (2017). Penerapan Model Pembelajaran Kooperatif Snowball Throwing untuk Meningkatkan Hasil Belajar Siswa pada Pembelajaran IPS. Jurnal Cakrawala Pendas, 3(2), 29-36.

Sandi, K. (2014). Pengaruh Model Pembelajaran Snowball throwing Terhadap Hasil Belajar IPA Dengan Kovariabel Kemampuan Berpikir Kreatif Siswa Kelas IV SD. Jurnal Mimbar PGSD Universitas Pendidikan Ganesha Mimbar PGSD, 2(1).

Shoimin, A. (2014). 68 Model Pembelajaran Inovatif dalam Kurikulum 2013. yogyakarta: Ar-Ruzz Media.

Sugiyono. (2015). Metode Penelitian Pendidikan Pendekatan Kuantitatif,Kualitatif, dan R\&D. Bandung: Alfabeta. 
Susanti, A. (2014). Pengaruh Model Snowball throwing Berbantuan Media Konkret Terhadap Hasil Belajar IPA Kelas V Sd Gugus I Gusti Ngurah Rai Denpasar. E-Journal PGSD Pendidikan Ganesha Mimbar $P G S D, 2(1)$.

Suyono, H. (2011). Belajar dan Pembelajaran. Bandung: Remaja Rosdakarya.

Winahyu, T. (2016). Penerapan Model Pembelajaran Snowball Throwing Guna Meningkatkan Aktivitas dan Hasil Belajar Siswa Kelas XI IPS 2 SMA Negeri 1 Mojosari. Avatara, e-Journal Pendidikan Sejarah, $4(1), 230-244$. 